\title{
In-Vitro antioxidant, anti-lipid peroxidative activities and In-Silico study of Terminalia chebula bioactive compounds
}

\author{
Syed Mubashar Sabir ${ }^{1 *} \mathbb{D}$, Syed Rizwan Abbas², Shabnam Shahida ${ }^{1}$ and Muhammad Faraz Khan ${ }^{3}$
}

\begin{abstract}
Objective: To evaluate the antioxidant activities and to identify the bioactive compounds in hot water extracts of Terminalia chebula fruit.

Methods: The antioxidant activities were determined by DPPH assay, lipid peroxidation assay, iron chelation and total antioxidant assay. The phenolic composition was determined by HPLC-DAD. Human Rab8b Protein was used for the validation of compounds as anti-inflammation. String analysis for protein synergism was used.

Results: The analysis of Terminalia chebula Retzius (Combretaceae) phenolics showed anti-inflammatory effect. The specific phenolic compositions were determined by high performance liquid chromatography (HPLC) and resulted in the identification of rutin, catechin, caffeic acid, gallicacid, ellagic acid, epicatechin, and quercetin as antioxidant compounds. Human Rab8b protein is selected for protein docking and all compounds except rutin showed good results. ADMET properties were checked by using AdmetSar and all seven compounds showed validation for AMET properties. The synergisms of compounds were analyzed by STRING analysis and our ligands shows strong binding with human Rab8b proteins. The aqueous extract was capable of inhibiting the lipid peroxidation in egg yolk phospholipid homogenate. The extract scavenged the 2,2-diphenyl-1-picrylhydrazyl radical (DPPH) (IC $50,71.5 \pm$ $2.1 \mu \mathrm{g} / \mathrm{ml}$ ). The extract displayed the high metal chelation activities and reducing abilities on the phosphomolybdenum assay.
\end{abstract}

Conclusions: It is concluded that extracts of T. chebula have good antioxidant and anti-inflammation activities and are rich in phenolics.

Keywords: Terminalia chebula, Protein docking, Lipid peroxidation, STRING analysis, Metal chelation, HPLC analysis

\section{Introduction}

Biomolecules such as DNA, lipids, proteins and RNA are damaged by oxidative stress, in human body that results in lipid peroxidation, injury to cells, impairment of tissues and gene mutation. Aging is due to free radicals and free radical cause different diseases like cardiovascular disorders, cancer, neurodegenerative diseases, inflammation [1]. In addition, lipid peroxidation caused by free radicals results in spoilage of

\footnotetext{
* Correspondence: mubashersabir@yahoo.com

1 Department of Chemistry, University of Poonch, Rawalakot Azad Kashmir,

Pakistan

Full list of author information is available at the end of the article
}

food during processing and storage [2]. Currently interest in antioxidant compounds has increased because they play essential role in health and diseases and also have nutritive value.

Terminalia chebula Retzius (Combretaceae), is an important medicinal plant which exhibits many medicinal activities due to its rich phytochemical composition. The plant's crown is round and its branches are spread, its bark is dark brown in color and has cracks along its length. The leaves are elliptical and the petiole's top is occupied with two large
Springer Open (c) The Author(s). 2020 Open Access This article is licensed under a Creative Commons Attribution 4.0 International License, which permits use, sharing, adaptation, distribution and reproduction in any medium or format, as long as you give appropriate credit to the original author(s) and the source, provide a link to the Creative Commons licence, and indicate if changes were made. The images or other third party material in this article are included in the article's Creative Commons licence, unless indicated otherwise in a credit line to the material. If material is not included in the article's Creative Commons licence and your intended use is not permitted by statutory regulation or exceeds the permitted use, you will need to obtain permission directly from the copyright holder. To view a copy of this licence, visit http://creativecommons.org/licenses/by/4.0/. 
glands at its tip. The fruit size is approximately $1-2$ in. The fruit of the plant has five lines present on its skin and has shown protective effect against liver damage induced by $\mathrm{CCl}_{4}$ and tert-butyl hydroperoxide [3]. The fruits also display cytoprotective [4], antidiabetic [5], antioxidant [6], antibacterial [7], anti-arthritic [8], hypo-cholesterolaemic [9] and antiinflammatory activities [10]. Chebulanin, chebulinic acid, 1,6-di-O-galloyl-b-D-glucose and Casuarinin were isolated from $T$. chebula and showed significant antioxidant activity [11]. The fruits of Terminalia chebula are added to salads and are used in food preserves [12].

The search of literature has shown that there is less information on antioxidant and phytochemical analysis of hot water extracts of Terminalia chebula. Moreover, hot water extracts are traditionally used in preparation of teas from fruit of Terminalia chebula. The antioxidant activities of plants are different when different prooxidants are used. In this study, the iron and sodium nitroprusside are used to induce lipid peroxidation in phospholipid homogenate and the antioxidant effect of aqueous extract was studied. Hence, this study was aimed to determine the composition of phenolics by HPLC and in vitro antioxidant activities of aqueous extract using different assays.

\section{Materials and methods Chemicals}

Standards used in HPLC analysis were purchased from Sigma Aldrich. Iron, sodium nitroprusside, DPPH, ammonium molybdate and 1,10-phenanthroline were purchased from Biochemicals (Lahore, Pakistan).

\section{Preparation of fruit extract}

The fruits of plant were locally purchased, identified by a botanist and a voucher specimen was deposited at the Herbarium of University of Poonch, Department of Botany (Ref. No. BOT/2017/51).

Finely grounded fruit material of the plant $(25 \mathrm{~g})$ was placed for $15 \mathrm{~min}$ in boiling water $(500 \mathrm{ml})$ was cooled and filtered with filter paper No. 1 (Pore size, $11 \mu \mathrm{M}$ ). The solvent was evaporated by rotary evaporator $\left(45^{\circ} \mathrm{C}\right)$ producing $3 \mathrm{~g}(12 \% \mathrm{w} / \mathrm{w})$ extract.

\section{In vitro lipid peroxidation assay}

The anti-lipid peroxidative properties of aqueous extracts were studied by a method [13]. In brief the egg yolk was weighed to $1 \mathrm{~g}$ and diluted to $100 \mathrm{ml}$ with 100 $\mathrm{mM}$ Tris- $\mathrm{HCl}, \mathrm{pH} 7.4$ and used as homogenate. The homogenate was incubated with $\mathrm{Fe}$ (II) or sodium nitroprussside with or without the extract and colour reaction was carried out by adding $600 \mu \mathrm{l}$ of TBA and $600 \mu \mathrm{l}$ of acetic acid ( $\mathrm{pH} 3.4)$ for $1 \mathrm{~h}$. The tubes were cooled and $2 \mathrm{ml}$ of $\mathrm{n}$-butanol was finally added and centrifuged. The absorbance was read at spectrophotometer at $532 \mathrm{~nm}$.

\section{DPPH radical scavenging activity}

The scavenging of the DPPH radical was reported by the method [14]. Briefly, a $0.25 \mathrm{mM}$ solution of the DPPH radical $(0.5 \mathrm{~mL})$ was added to a sample solution in ethanol $(1 \mathrm{~mL})$ at different concentrations $(25-400 \mu \mathrm{g} / \mathrm{mL})$ of the aqueous extracts. The mixture was shaken vigorously and left to stand for $30 \mathrm{~min}$ in the dark, then the absorbance was measured at $517 \mathrm{~nm}$. The capacity to scavenge the DPPH radical was calculated using the equation:

$$
(\%) \text { scavenging }=[(\text { AoA } 1) / \text { Ao })] \times 100
$$

Where, Ao is the absorbance of the control reaction and $\mathrm{A} 1$ is the absorbance of the sample.

\section{Metal chelating activity}

The iron chelating ability of the aqueous extract was studied by the method [15]. Briefly $150 \mu \mathrm{L}$ of freshly formed $2 \mathrm{mM} \mathrm{FeSO} \cdot 7 \mathrm{H}_{2} \mathrm{O}$ was added in a mixture which have $168 \mu \mathrm{L}$ of the $0.1 \mathrm{M}$ tris $\mathrm{HCl}$ (pH 7.4), $(218 \mu \mathrm{L})$ of saline and $(25-200 \mu \mathrm{L} / \mathrm{ml})$ concentration of plant extracts. The mixture of sample was incubate for 5 min before addition of $13 \mu \mathrm{L}$ of $0.25 \% 1,10$-phenanthroline (w/v). Absorbance was checked at $510 \mathrm{~nm}$ in spectrophotometer.

\section{Antioxidant potential assay}

The reducing ability of the aqueous extract was followed by phosphomolybdenum method [16]. The

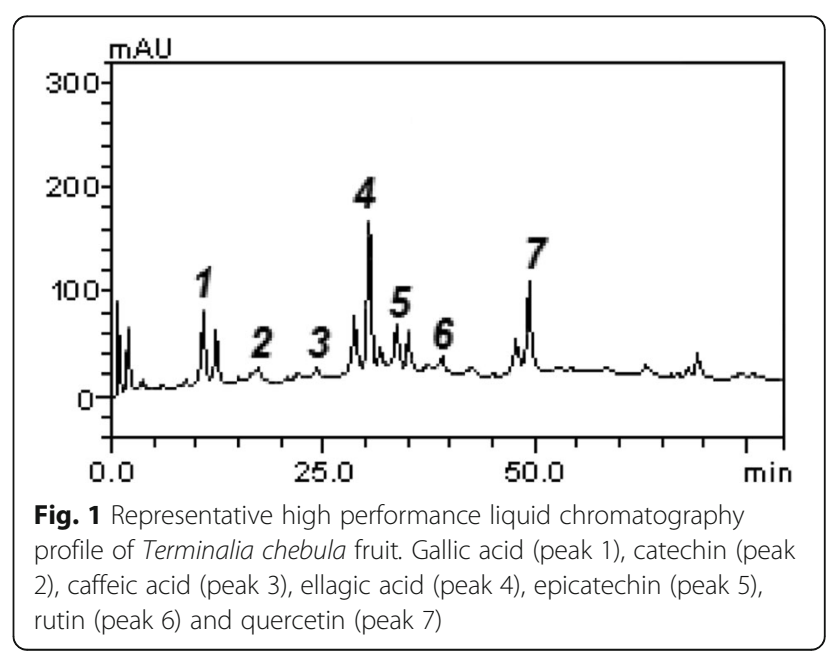



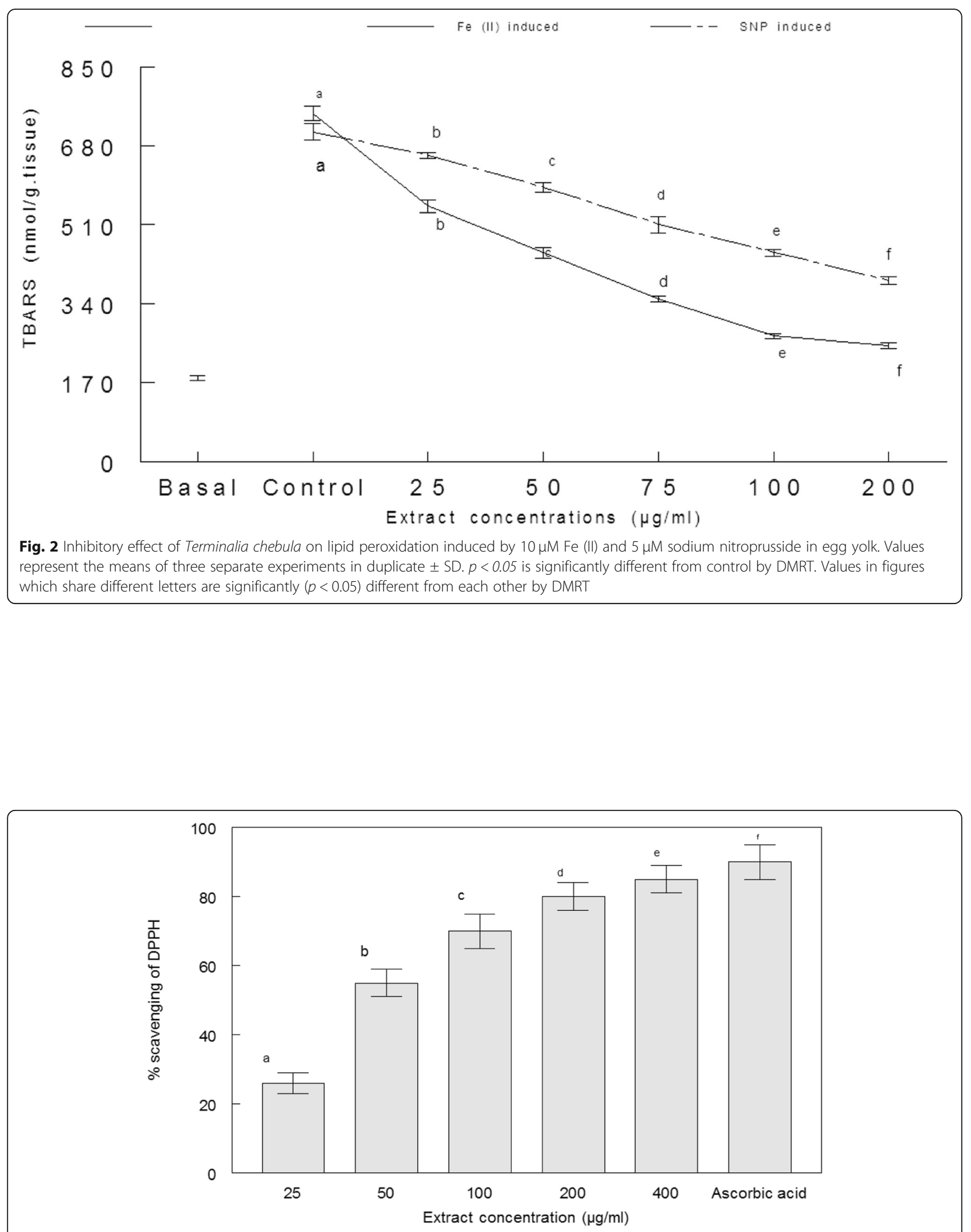

Fig. $3 \mathrm{DPPH}$ radical scavenging activity of aqueous extract obtained from fruit of Terminalia chebula. Ascorbic acid at concentration of $100 \mu \mathrm{g} / \mathrm{ml}$. Values are means \pm SD $(n=3)$. Values in figures which share different letters are significantly $(p<0.05)$ different from each other by DMRT 


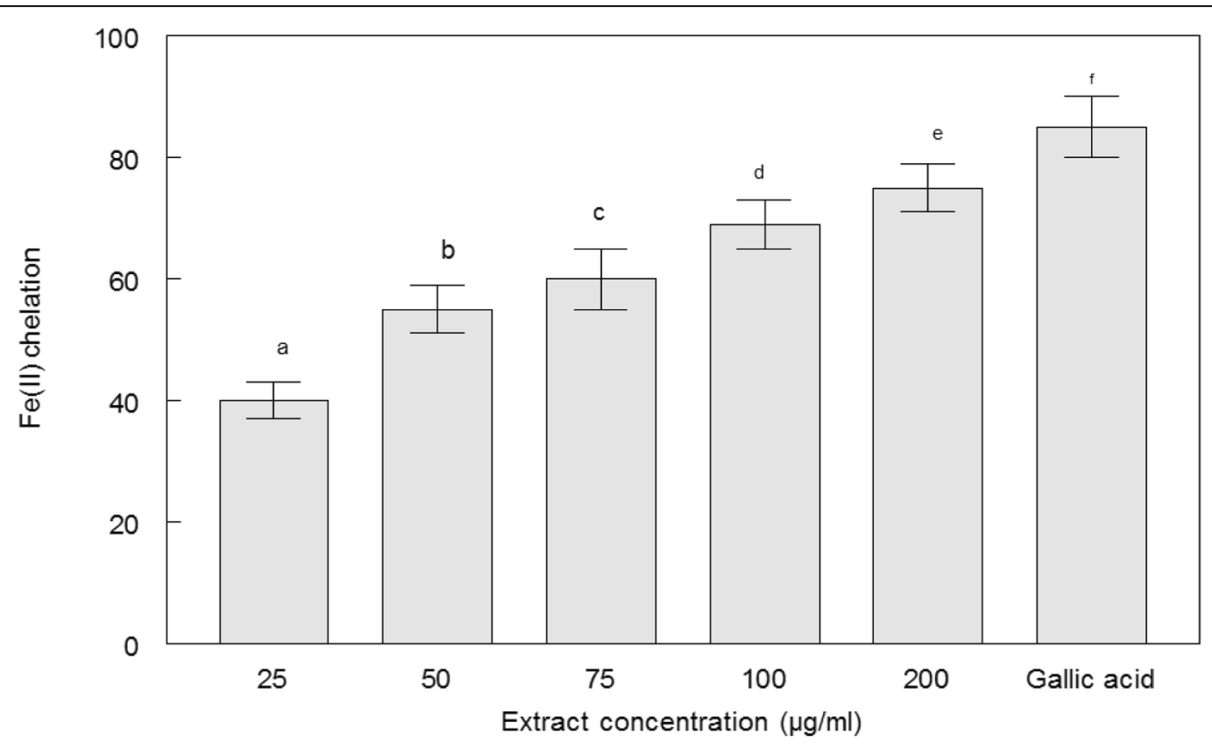

Fig. 4 Iron chelating abilities of Terminalia chebula fruit extract. Gallic acid at concentration of $50 \mu \mathrm{g} / \mathrm{ml}$. Values are means $\pm S D(n=3)$. Values in figures which share different letters are significantly $(p<0.05)$ different from each other by DMRT

results were expressed as ascorbic acid equivalent. The assay was based on the reduction of molybdenum, Mo (VI)-Mo(V) by the extract and subsequent formation of a green phosphate $/ \mathrm{Mo}(\mathrm{V})$ complex at acidic $\mathrm{pH}$. The extract $(0.1 \mathrm{mg} / \mathrm{ml})$ was mixed with $3 \mathrm{ml}$ of the reagent solution $(0.6 \mathrm{M}$ $\mathrm{H} 2 \mathrm{SO} 4,28 \mathrm{mM}$ sodium phosphate and $4 \mathrm{mM}$ ammonium molybdate). The tubes were incubated at $95 \mathrm{C}$ for $90 \mathrm{~min}$. The mixture was cooled to room temperature and the absorbance of the solution was measured at $695 \mathrm{~nm}$.

\section{HPLC analysis of phenolics and flavonoids}

T. chebula aqueous extract $(1 \mathrm{mg} / \mathrm{mL})$ was dissolved in HPLC grade methanol filtered and subjected for analysis by Shimadzu HPLC system as reported by Khaliq et al., [13].

\section{Molecular docking}

Human Rab8b Protein was used for the validation of compounds as anti-inflammation. The 3D structures of protein were downloaded from RCSB database. For docking PyRxvina docks tool were used.

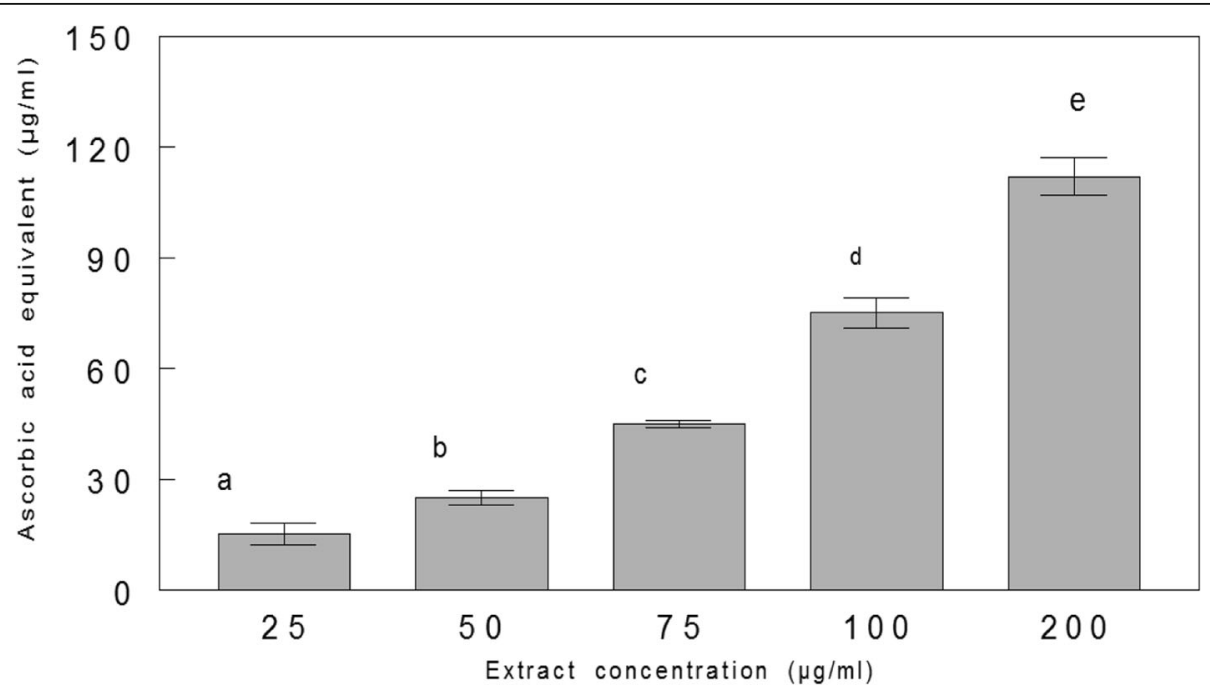

Fig. 5 Total antioxidant activity of Terminalia chebula fruit extract. Values are means $\pm \operatorname{SD}(n=3)$. Values in figures which share different letters are significantly $(p<0.05)$ different from each other by DMRT 

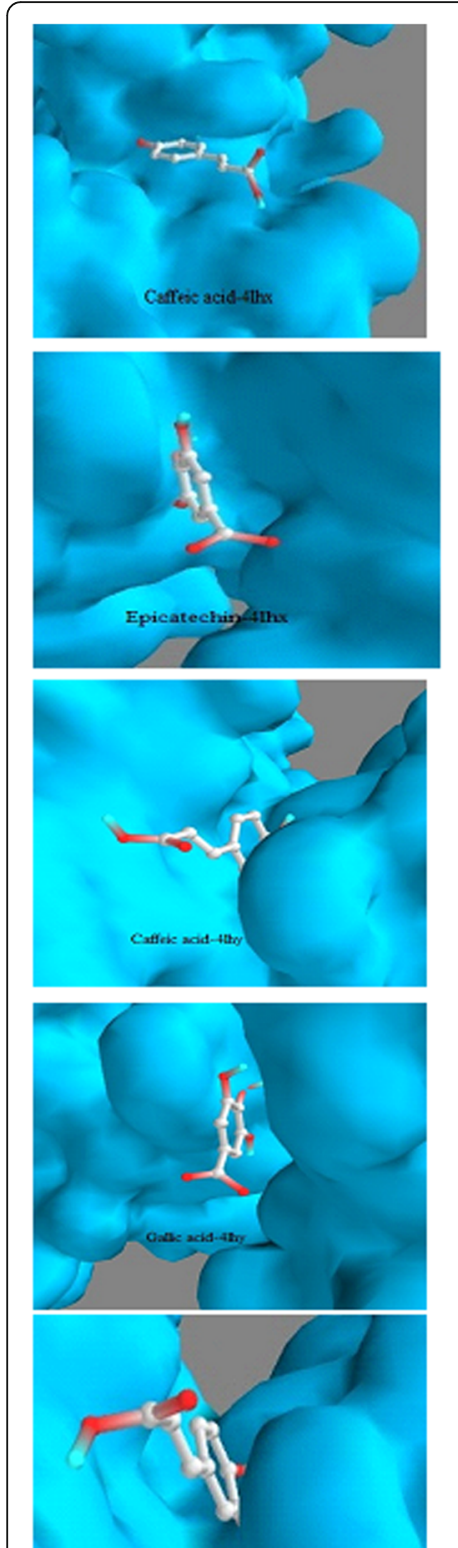

Caffeic acid-4lhz

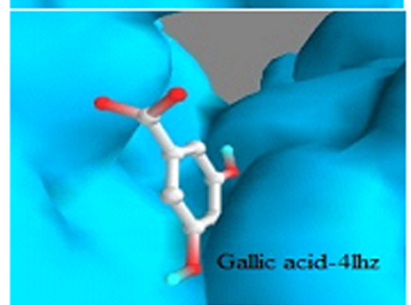

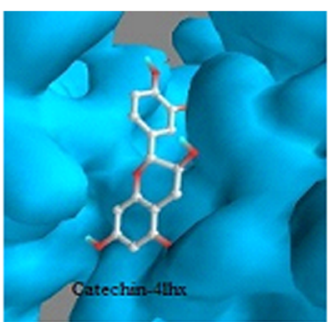
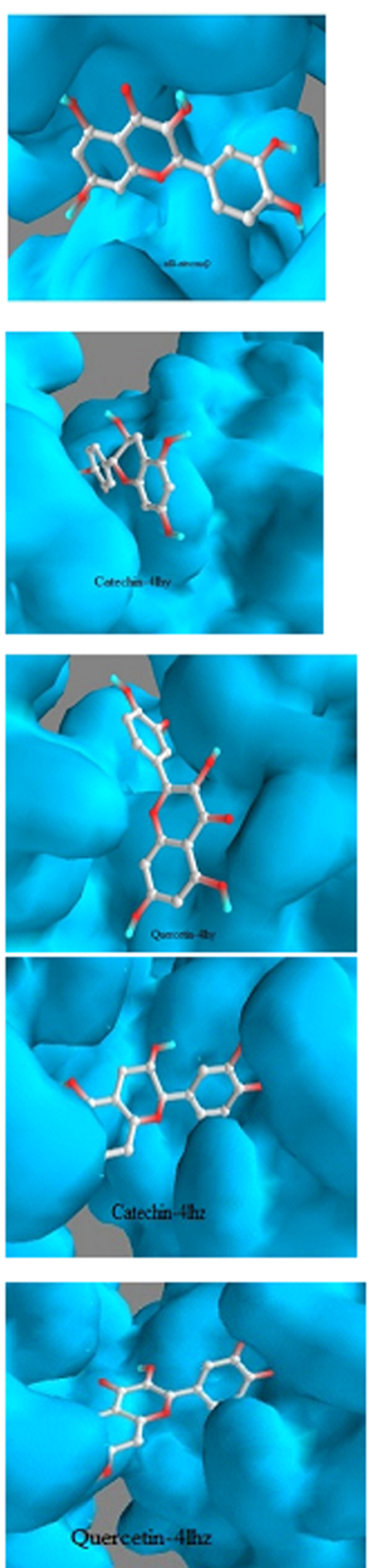
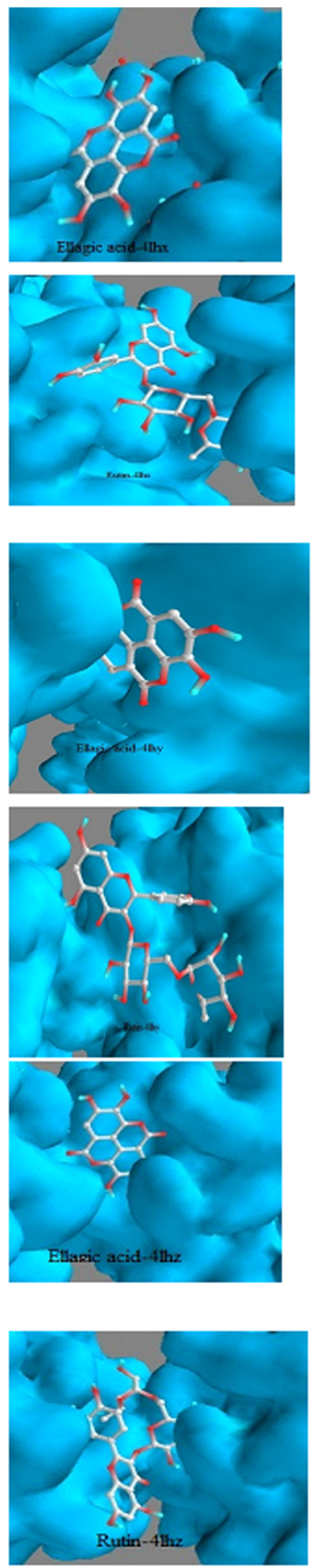

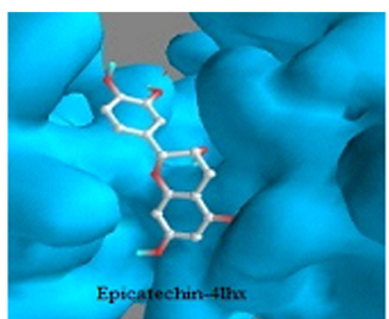

Binding pose of ligands in the binding pocket of 4hx

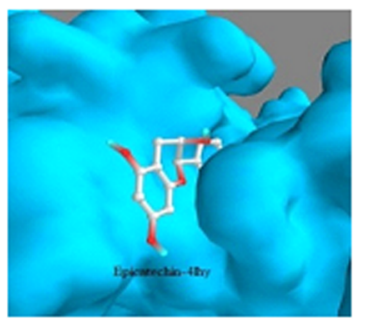

Binding pose of ligands in the binding pocket of 4hy

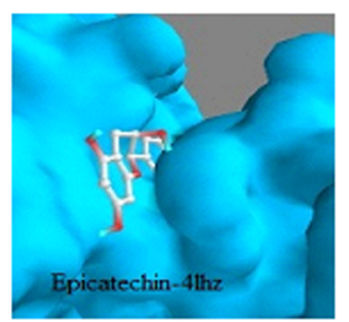

Binding pose of ligands in the binding pocket of 4thz

Fig. 6 Binding poses of the Ligands in the binding pockets of human Rab8b proteins with a surface view of the proteins 
Table 1 Affinity score of ligand with Human Rab8b proteins

\begin{tabular}{lccc}
\hline Ligand & 4lhx & 4lhy & 4/hz \\
\hline Caffic Acid & -5.8 & -5.7 & -5.8 \\
Catechin & -6.4 & -6.7 & -6.9 \\
Ellagic Acid & -7.2 & -7.3 & -7.6 \\
Epicatechin & -6.6 & -6.6 & -6.7 \\
Gallic Acid & -5.5 & -5.5 & -5.5 \\
Quercetin & -6.6 & -6.7 & -6.6 \\
Rutin & -7.1 & -7.1 & -8.1 \\
\hline
\end{tabular}

\section{Synergism of compounds}

String is a free online software to analysis protein interactions. To check the synergism between compounds relevant protein of the compounds were analyzed.

\section{Data analysis}

The results were expressed as means \pm SD. The obtained data was analyzed by one way ANOVA and different group means were compared by Duncan Multiple Range Test (DMRT) wherever necessary; $p<0.05$ was considered significant in all cases. Statistica (version 4.5; StatSoft Inc., Tulsa, OK, USA) was used as software package.

\section{Results}

In HPLC chromatogram of Terminalia chebula fruit extract the peak of gallic acid appeared at retention time of $10.18 \mathrm{~min}$ (peak 1), catechin at $16.53 \mathrm{~min}$ (peak 2), caffeic acid at 24.09 min (peak 3), ellagic acid at 30.15 (peak 4), epicatechin at 33.78 min (peak 5), rutin at $39.04 \mathrm{~min}$ (peak 6) and quercetin at 49.56 min respectively (Fig. 1).

Lipid peroxidation in phopholipid homogenate was stimulated when iron and SNP were used as prooxidant. The Thiobarbituric acid reactive species (TBARS) production was enhanced to $79 \%$ in phospholipid homogenate compared to the basal or normal (Fig. 2). However, treatment with Terminalia chebula shunted the lipid peroxidation in control treatments compared to the control.
The DPPH activity of $T$. chebula is shown in Fig. 3. The activity was the highest at $200 \mu \mathrm{g} / \mathrm{mL}$, with an $\mathrm{IC}_{50}$ value of $45.5 \pm 2.1 \mu \mathrm{g} / \mathrm{mL} \quad\left(r^{2}=0.971\right)$. The vitamin $\mathrm{C}$ showed an $\mathrm{IC}_{50}$ value $31 \pm 1.1 \mu \mathrm{g} / \mathrm{mL}$ $\left(r^{2}=0.97\right)$. The extract was effective in chelating iron from the mixture (Fig. 4). The chelating ability was increased when concentration was raised and comparable to the standard gallic acid. The phosphomolybenum assay is an indirect method which measures the total antioxidant activities. In the phosphomolybdenum assay, the extract showed their ability to donate electrons and showed an antioxidant activity of $111 \pm 2.5 \mu \mathrm{g} / \mathrm{ml}$ as ascorbic acid equivalent at a maximal concentration $(200 \mu \mathrm{g} / \mathrm{mL})$ (Fig. 5). Molecular docking was done by using PyRx software and the given results were shown in Table 1 and pose of ligand on Human protein Rab8b were showed in (Fig. 6). All AMET characters were checked by using AdmetSar and results are showed in Tables 1, 2, 3. All compound showed good results for Lipinski rules (Table 3). The synergism of all compounds were analyzed by using STRING analysis (Fig. 7).

\section{Discussion}

Some important natural products such aschebulic acid, chebulagic acid, corilagin, mannitol, gallic acid, ellagic acid, tannic acid, ethyl gallate, and ascorbic acid were detected in the extracts of $T$. chebula [17]. T. chebula was rich in tannins (32\%) [18]. Here the HPLC analysis has revealed the presence of gallic acid $(4.97 \pm 0.01 \mathrm{mg} / \mathrm{g})$, catechin $(0.83 \pm 0.03 \mathrm{mg} / \mathrm{g})$, caffeic acid $(0.56 \pm 0.04 \mathrm{mg} / \mathrm{g})$, ellagic acid $(9.15 \pm 0.01 \mathrm{mg} / \mathrm{g})$, epicatechin $(2.74 \pm 0.02 \mathrm{mg} / \mathrm{g})$, rutin $(0.80 \pm 0.05 \mathrm{mg} / \mathrm{g})$ and quercetin $(6.03 \pm 0.03 \mathrm{mg} / \mathrm{g})$ in aqueous extract of Terminalia chebula fruit (Table 4). Plants are rich in phenolic compounds which inhibit the lipid peroxidation by neutralizing the free radical species $[19,20]$.

This study focused on the anti-lipid peroxidative properties of $T$. chebula in egg yolk phospholipid. Iron stimulated the lipid peroxidation as it can generate one electron transfer reaction and increases the

Table 2 Predicted Absorption of seven Ligands

\begin{tabular}{|c|c|c|c|c|c|c|c|}
\hline & Caffeic acid & Catechin & Ellagic acid & Epicatechin & Gallic acid & Quercetin & Rutin \\
\hline Blood-Brain Barrier & BBB- & BBB- & $\mathrm{BBB}+$ & BBB- & BBB- & BBB- & BBB- \\
\hline Human Intestinal Absorption & $\mathrm{HIA}+$ & $\mathrm{HIA}+$ & $\mathrm{HIA}+$ & $\mathrm{HIA+}$ & $\mathrm{HIA+}$ & $\mathrm{HIA+}$ & $\mathrm{HIA}+$ \\
\hline Caco-2 Permeability & $\mathrm{Caco} 2+$ & Caco2- & Caco2- & Caco2- & Caco2- & Caco2- & Caco2- \\
\hline P-glycoprotein Substrate & Non-substrate & Substrate & Substrate & Substrate & Non-substrate & Substrate & Substrate \\
\hline P-glycoprotein Inhibitor & Non-inhibitor & Non-inhibitor & Non-inhibitor & Non-inhibitor & Non-inhibitor & Non-inhibitor & Non-inhibitor \\
\hline Renal Organic Cation Transporter & Non-inhibitor & Non-inhibitor & Non-inhibitor & Non-inhibitor & Non-inhibitor & Non-inhibitor & Non-inhibitor \\
\hline
\end{tabular}


Table 3 Lipinski rule

\begin{tabular}{lllllllllll}
\hline & MW & AlogP & Hdon & Hacc & OB (\%) & Caco-2 & BBB & DL & FASA- & TPSA \\
\hline Caffeic acid & 180.17 & 1.37 & 3 & 4 & 54.97 & 0.27 & 0.11 & 0.05 & 0 & 77.76 \\
Catechin & 290.29 & 1.92 & 5 & 6 & 54.83 & -0.03 & -0.73 & 0.24 & 0 & 110.38 \\
ellagic acid & 302.2 & 1.48 & 4 & 8 & 43.06 & -0.44 & -1.41 & 0.43 & 0.43 & 141.34 \\
epicatechin & 290.29 & 1.92 & 5 & 6 & 48.96 & 0.02 & -0.64 & 0.24 & 0.34 & 110.38 \\
gallic acid & 170.13 & 0.63 & 4 & 5 & 31.69 & -0.09 & -0.54 & 0.04 & 0.41 & 97.99 \\
Quercetin & 302.25 & 1.5 & 5 & 7 & 46.43 & 0.05 & -0.77 & 0.28 & 0.38 & 131.36 \\
Rutin & 610.57 & -1.45 & 10 & 16 & 3.2 & -1.93 & -2.75 & 0.68 & 0 & 269.43 \\
\hline
\end{tabular}

production of reactive oxygen species. The overload of Iron results in the implication of different diseases such as cancer, hepatic, cardiac, brain disorder and neurodegenerative disorders [21]. It is evident from the results (Fig. 2) that the aqueous extract of $T$. chebula are capable of causing significant $(P<0.05)$ inhibition of lipid peroxidation which is partly due to its iron chelating abilities.

Increase in lipid peroxidation is strong indicator of tissues damage due to excess of iron and SNP. In biological system sodium nitroprusside (SNP) decompose to generate nitric oxide $\left(\mathrm{NO}^{\circ}\right)$ radical [22]. The released NO reacts with other reactive oxygen species (ROS) notably superoxide radical to form peroxynitrite radical [23]. Terminalia chebula has reduced the lipid peroxidation induced by SNP, as the water extractable phytochemicals of the plant scavenge the $\mathrm{NO}^{\circ}$ produced by the SNP, thus protecting the phospholipids against oxidative stress [23]. DPPH method is a fast and simple method which is in routine screens the antioxidant activities of plant extracts and synthetic compounds. The DPPH free radical being soluble in ethanol showed reduction on treatment with extract. T. chebula showed high percentage scavenging of the DPPH radical.

Table 4 Composition of Terminalia chebula fruit

\begin{tabular}{lll}
\hline Compounds & Extract & \\
\cline { 2 - 3 } & $\mathbf{m g} / \mathbf{g}$ & $\%$ \\
\hline Gallic acid & $4.97 \pm 0.01 \mathrm{a}$ & 0.49 \\
Catechin & $0.83 \pm 0.03 \mathrm{~b}$ & 0.08 \\
Caffeic acid & $0.56 \pm 0.04 \mathrm{c}$ & 0.05 \\
Ellagic acid & $9.15 \pm 0.01 \mathrm{~d}$ & 0.91 \\
Epicatechin & $2.74 \pm 0.02 \mathrm{e}$ & 0.27 \\
Rutin & $0.80 \pm 0.05 \mathrm{~b}$ & 0.08 \\
Quercetin & $6.03 \pm 0.03 \mathrm{c}$ & 0.60 \\
\hline
\end{tabular}

Results are expressed as mean \pm standard deviations (SD) of three determinations

Averages followed by different letters differ by Turkey test at $p<0.01$
Iron chelation assay is indirect method of evaluating the antioxidant activity. O-phenanthroline is a chemical which selectively chelates iron. Chelating agent reacts with $\mathrm{O}$-phenanthroline and thus disrupts the complex formation and thus intensity of the color is decreased in the assay. T. chebula extract showed dose dependent scavenging of ferrous ions. Enhanced oxidative stress caused by ferrous ions leads to the many diseases like Alzheimer's syndrome which is a life threatening disease [24]. Naturally plants contain phytochemicals which are responsible for the metal chelation and thus reduce the lipid peroxidation [25].

In phosphomolybdenum method the Mo (VI) is reduced to its less common Mo (V) by the active compounds present in the extract. The absorbance of sample increases compared to the control which is indicative that the extract is capable of donating hydrogen atoms.

To check the strength of ligands (compounds) against inflammation, we used human Rab8b protein as a target for docking. Three proteins were selected i.e. 4lhx, 4lhy and 4lhz. In the molecular docking study, the X-ray structure of human Rab8b proteins were used to dock with our ligands. This regulation is particularly important in immune cells for mounting specialized immune defenses. By controlling the formation, transport and fusion of intracellular organelles, Rab8b serve as master regulators of membrane trafficking. As a result of cellular and molecular mechanisms Rab8b regulate immunity and inflammation.

The results of the PyRx docking showed a docking scores of -5.5 to $-8.1 \mathrm{kcal} / \mathrm{mol}$ against the protein. Our ligands are capable of binding with human Rab8b proteins as well as show affinity toward the surrounding amino acids.

\section{Conclusion}

In conclusion, HPLC-DAD method was effectively utilized to determine the phenolic compounds in $T$. chebula fruit. Seven phenolic compounds were 


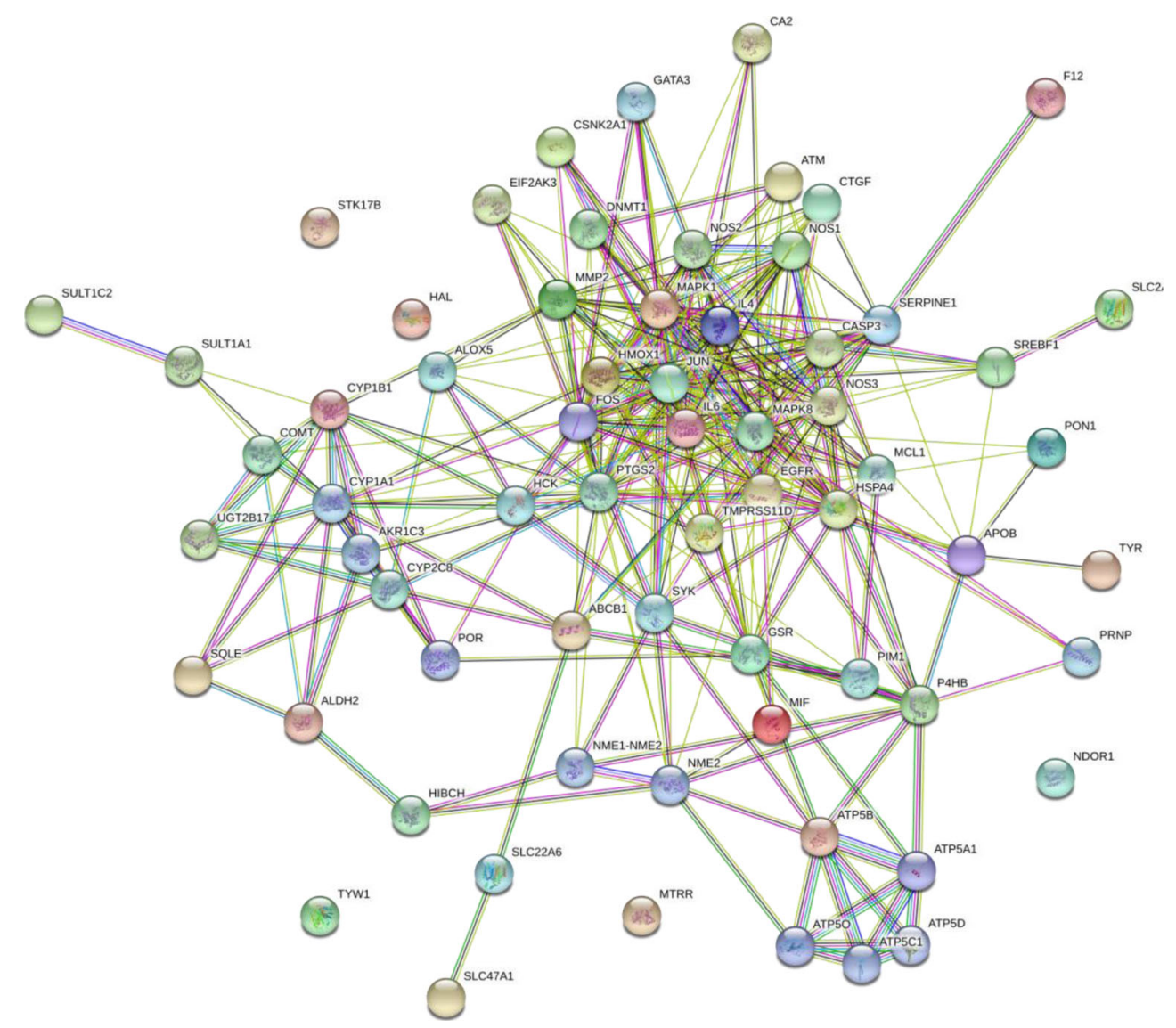

\section{KEGG Pathways}

Pathway ID pathway description count in gene set false discovery rate 05206 MicroRNAs in cancer $111.17 \mathrm{e}-10$

01100 Metabolic pathways $197.98 \mathrm{e}-08$

04066 HIF-1 signaling pathway $72.23 \mathrm{e}-06$

05133 Pertussis63.86e-06

05204 Chemical carcinogenesis 63.86e-06

\section{(more ...)}

Fig. 7 Network and enrichment analysis showing results obtained upon entering a set of 61 proteins suspected to be involved in Amyotrophic Lateral Sclerosis (55). In the bottom inset, one enriched function has been selected, and the corresponding protein nodes in the network are automatically highlighted in color

identified in the fruit. Crude extracts of T. chebula possess different biological activities such as DPPH radical scavenging activity, reducing activities and anti-lipid peroxidative properties. Molecular docking of ligands was shown high affinity for antiinflammation. All seven compounds showed validation for AMET properties. The synergism of all compounds is shown strength against inflammation. This justifies the use of the fruit in nutrition, industries and medicines. However, more systematic understandings of in vivo and in silico studies and safety evaluation are required.

\section{Acknowledgements}

Not applicable

\section{Authors' contributions}

SM Sabir designed the study and wrote the manuscript. SR Abbas performed the In-silico studies. S Shahida is responsible for organization of the results and manuscript editing. MF Khan performed the statistical analysis. All the authors have read and approved the final manuscript. 
Funding

Not applicable

\section{Availability of data and materials}

Not applicable

Ethics approval and consent to participate

Not applicable

\section{Consent for publication}

Not applicable

\section{Competing interests}

The authors declare that no competing interest involved in the study.

\section{Author details}

'Department of Chemistry, University of Poonch, Rawalakot Azad Kashmir, Pakistan. ${ }^{2}$ Department of Biological Sciences, Hunza Campus, Karakoram International University, Gilgit, Pakistan. ${ }^{3}$ Department of Botany, University of Poonch, Rawalakot Azad Kashmir, Pakistan.

Received: 10 July 2020 Accepted: 25 November 2020

Published online: 05 December 2020

\section{References}

1. Pham-Huy LA, He H, Pham-Huy C. Free radicals, antioxidants in disease and health. Int J Biomed Sci. 2008:4:89-96.

2. Donnelly JK, Robinson DS. Free radicals in foods. Free Radic Res. 1995;22: 147-76.

3. Tasaduq SA, Singh K, Sethi S, Sharma SC, Bedi KL, Singh J, Jaggi BS, Johri RK Hepatocurative and antioxidant profile of HP-1, a polyherbal phytomedicine. Hum Exp Toxicol. 2003;22:639-45.

4. Minkyun NA, Wan BAE, Kang SS, Min BS, Yoo JK, Yuk OK, Yu-lchiro S, Sciichi $Y$, Nobuhiko M. Cytoprotective effect on oxidative stress and inhibitory effect on cellular aging of Terminialia chebula fruit. Phytother Res. 2004;18: 737-41

5. Senthilkumar GP, Subramanian SP. Biochemical studies on the effect of Terminaliachebula on the levels of glycoproteins in streptozotocin-induced experimental diabetes in rats. J Appl Biomed. 2008;6:105-15.

6. Lee HS, Jung SH, Yun BS, Lee KW. Isolation of chebulic acid from Terminaliachebula Retz. and its antioxidant effect in isolated rat hepatocytes. Arch Toxicol. 2007:81:211-8.

7. Malckzadeh F, Ehsanifar H, Shahamat N, Levin M, Colwell RR. Antibacterial activity of black myrobalan (Terminalia chebula Retz.) against Helicobactor pyroli. Int J Antimicrob Agents. 2001;18:85-8

8. Nair S, Singh YK, Gupta A. Anti-arthritic and disease modifying activity of Terminalia chebula Retz. in experimental models. J Pharm Pharmacol. 2010; 62:1801-6.

9. Israni DA, Patel KV, Gandhi TR. Anti-hyperlipidemic activity of aqueous extract of Terminalia chebula and Gaumutra in high cholesterol diet fed rats. Int J Pharm Sci. 2010;1:48-59.

10. Pratibha N, Saxena VS, Amit A, Souza PD, Bagchi M, Bagchi D. Antiinflammatory activities of Aller-7, a novel polyherbal formulation for allergic rhinitis. Int J Tissue React. 2004;26:43-51.

11. Cheng $H$, Lin T, Yu K, Yang C. Antioxidant and free radical scavenging activities of Terminalia chebula. Biol Pharm Bull. 2003;26:1331-5.

12. Ananymous. Terminalia chebula. 2017. http://www.onlyfoods.net/. Accessed 04 Jan 2018

13. Khaliq A, Sabir SM, Ahmad SD, Boligon AA, Athayde ML, Jabbar A, Qamar I, Khan A. Antioxidant activities and phenolic composition of olive (Oleaeuropae) leaves. J Appl Bot Food Qual. 2015;88:16-21.

14. Hatano T, Kagawa H, Yasuhara T, Okuda T. Two new flavonoids and other constituents in licorice root; their relative astringency and radical scavenging effects. Chem Pharm Bull. 1988;36:2090-7.

15. Puntel RL, Nogueira CW, Rocha JBT. Krebs cycle intermediates modulate thiobarbituric acid reactive species (TBARS) production in rat brain in vitro Neurochem Res. 2005;30:25-235.

16. Prieto P, Pineda M, Aguilar M. Spectrophotometric quantitation of antioxidant capacity through the formation of a phosphomolybdenum complex: specific application to the determination of vitamin E. Anal Biochem. 1999;269:337-41.
17. Grover IS, Bala S. Antimutagenic activity of T. chebula (myroblan) in Salmonella typhimurium. Indian J Exp Biol. 1992;30:339-41.

18. Chattopadhyay RR, Bhattacharyya SK. Plant review Terminalia chebula: an update. Pharmacogn Rev. 2007;1:151-6.

19. Newairy AA, Abdou HM. Protective role of flax lignans against lead acetateinduced oxidative damage and hyperlipidemia in rats. Food Chem Toxicol. 2009;47:813-8.

20. Juang LJ, Sheu SJ, Lin TC. Determination of hydrolyzable tannins in the fruit of Terminalia chebula by high-performance and capillary electrophoresis. J Sep Sci. 2004;27:718-24.

21. Milman N, Pedersen P, Steig T, Byg KE, Graudal N, Fenger K. Clinically overt hereditary hemochromatosis in Denmark 1948-1985: Epidemiology, factors of significance for long-term survival, and causes of death in 179 patients. Ann Hematol. 2001;80:737-44.

22. Miller MR, Megson IL. Recent developments in nitric oxide donor drugs. $\mathrm{Br}$ Pharmacol. 2007:151:305-21.

23. Berg RMG, Møller K, Bailey DM. Neuro-oxidative-nitrosative stress in sepsis. Cerebr Blood F Met. 2011:31:1532-44.

24. Ebrahimzadeh MA, Pourmorad F, Bekhradnia AR. Iron chelating activity, phenol and flavonoid content of some medicinal plants from Iran. Afr J Biotechnol. 2008;7:3188-92.

25. Khan A, Sabir SM, Nazar H, Hamid A, Usmanghani K, Ali H. Antioxidant activities and inhibitory effects of dietary plants against sodium nitroprusside induced lipid peroxidation in mouse brain and liver. Food Sci Biotechnol. 2014;10:10068-79.

\section{Publisher's Note}

Springer Nature remains neutral with regard to jurisdictional claims in published maps and institutional affiliations.

\section{Submit your manuscript to a SpringerOpen ${ }^{\circ}$ journal and benefit from}

- Convenient online submission

- Rigorous peer review

- Open access: articles freely available online

- High visibility within the field

- Retaining the copyright to your article

Submit your next manuscript at $>$ springeropen.com 